\title{
Defining And Assessing Team Skills Of Business And Accountancy Students
}

\author{
Nabil Alghalith, (Email: nabila@truman.edu), Truman State University \\ Michael Blum, Truman State University \\ Amanda Medlock, Truman State University \\ Sandy Weber, Truman State University
}

\begin{abstract}
The objectives of the project are (1) to define the skills necessary for students to work effectively with others to achieve common goals, and (2) to develop an assessment instrument to measure student progress toward achieving these skills. The defined skill set will form a basis for common expectations related to team skills that will be shared with students and be used by faculty for setting goals, planning curriculum and pedagogy, and assessing student progress. Assessment data will be incorporated into the Division of Business and Accountancy's Continuous Improvement Plan and assessment cycle. The significance of this project is to ensure and demonstrate student learning related to teamwork, which is one of the key elements of the Division's newly adopted vision statement. The ability to demonstrate continuous improvement related to the Division's mission is vital to the re-accreditation of the business program. This project incorporated input from the entire faculty of the Division, and the results will be used by the entire faculty and shared with students in order to communicate expectations. This participative process will serve to enhance the culture of assessment in the Business Division among faculty and students.
\end{abstract}

An original assessment instrument was developed to meet the needs of the Division's faculty, incorporating sources in the literature, results of a faculty survey, and student input obtained from portfolio entries. Results were disseminated in discipline and division meetings for faculty use, and will be available for sharing at the University planning day.

\section{Literature Review}



he Student Learning Committee (SLC) of the Division of Business \& Accountancy was charged with defining a set of team competencies and developing an assessment instrument to measure student progress in the development of these team competencies/skills.

The authors reviewed an article written by Steve Beebe and Kevin Barge entitled "Small Group Communication." It discusses several issues of concern three of which were: (1) the measurement of overt behaviors or predispositions, (2) should members self-report information or should more objective external observer's use the instrument to provide the data, (3) the fact that a well defined widely accepted set of competencies is not available in the literature. We also reviewed an instrument developed by the same authors Beebe and Barge. The assessment instrument was called: The Competent Group Communicator: An Instrument to Assess Problem Solving Group Discussion. This instrument looks specifically at problem solving groups and assesses group task functions such as defining the problem, analyzing the problem, identifying criteria for the solution, generating solutions, and evaluating solutions. It also explores discussion management such as keeping the group on task and appropriate group interaction. Additionally, the measure assesses relational functions such as conflict management and maintaining a positive group climate. The work of Larson and LaFasto examines characteristics that an effective team member should possess such as being action-oriented and supportive. The recipients also reviewed this. 
Methods

The project was discussed with the Business and Accountancy faculty at a Division meeting. Subsequent to providing them information about the project the faculty formed six groups to respond to the following question: Disregarding the content of the project, what are the team skills we are hoping to develop in students when we design group and team activities.

The authors reviewed the responses provided by the faculty independently. Analysis of the responses revealed some common themes, which allowed for the development of an initial set of competencies. A list of twenty competencies was created. Further discussion led to the decision to classify each competency as either task or relational. Additional competencies were added based on Beebe and Barge's work, the work of Lafasto and Larson, and the data provided by the faculty of the Division. The first draft of the assessment instrument was created and then refined to use a behavioral anchored rating scales rather than the format used by Lafasto and Larson.

After discussion of the advantages of each the different formats for the assessment instrument. We decided to use the behavioral anchors as an evaluation of various sets of competencies. It was determined the Division would not need more detailed information than that provided by the evaluation of these sets of competencies. In addition, we supplemented the behavioral anchored scales with a checklist of selected specific competencies so as to improve the feedback that could be given to the students.

It was decided that individual members write independently verbal descriptions of each set of competencies. These descriptions would be shared with the users of the assessment instrument (i.e. the students and faculty) to give them a better understanding of each behavioral anchored rating scale.

Some of the verbal descriptions of the competency sets were written. The final draft of the assessment instrument was written. The authors reviewed and edited the final assessment instrument, which will be tested during the 2003-04 academic year.

\section{Tasks for Completion of the Project}

Data will be gathered from students and faculty as to the competencies of students in the area of teamwork. This data will be analyzed by the Division's Student Learning Committee and others to determine: a) Whether modifications to the assessment instrument need to be made and/or b) Changes in where (i.e. which classes) the assessment of student team competencies is made within the Division and/or c) Changes in the curriculum need to be made to further enhance student acquisition of these team competencies.

\section{Bibliography}

1. Beebe, Steven A. and J. Kevin Barge, Assessing Small Group Problem Solving Communication Competence.

2. Lafasto, F. \& Larson, C. (2001). When teams work best: 6,000 team members and leaders tell what it takes to succeed. Thousand Oaks, CA: Sage. 


\section{Description of Effective Team Member Competencies For Team Skills Rubric}

The five competencies of an effective team member are described below. The first three competencies (organization/coordination, participation, and problem solving) deal with maintaining structure in team, which includes the organization team meetings, the assignment of roles and tasks, the definition of goals, and the active participation of all team members in order to effectively complete the team's tasks. The final two competencies (group dynamics and conflict resolution) deal with a team's interaction or the give-and-take dialogue among team members. Team members must promote effective communication in order to develop healthy relationships and cohesiveness. An effective team maintains a balance between structure and interaction. This balance allows team members to feel comfortable contributing to discussion and have a positive attitude about being a part of the team while maintaining a strong focus on the team's goals.

\section{Task/Structure Competencies}

\section{Competency 1: Organization/Coordination}

A team member who offers organization and coordination to a team helps in organizing the structure of team meetings by keeping the group focused on the task at hand and the team goals. In order to organize the team, the goals of the team will be clearly identified and defined. In addition, a team member competent in this area will work to coordinate the efforts of team members by assisting in the clear definition of roles and tasks that each team member should complete as well as developing deadlines. A member with strong coordination skills will work to integrate ideas from all team members into the final product. This competency emphasizes mutual leadership among team members or a shared commitment and responsibility for the team reaching its goal.

\section{Competency 2: Participation}

A team member participates by not only attending meetings regularly and punctually but also contributes to the team by carrying his/her share of the responsibility for tasks that must be completed outside team meetings. Tasks are completed in a timely fashion and are of high quality.

\section{Competency 3: Problem Solving}

Teams are often called upon to make a decision or solve a problem; therefore, team members should be able to contribute effectively to the problem solving process. Dewey's reflective thinking model serves as a basis for the areas assessed in problem solving (1. clearly define the problem, 2. analyze the problem, 3. generate solutions, 4. evaluate and select the best solution). Defining the problem is covered in competency one (organization/coordination) with the defining of goals. A competent team member will contribute research and/or information about the given problem in order to effectively analyze all aspects of the problem. Next, a competent team member will contribute to the brainstorming of creative solutions to the problem. Multiple solutions should be generated freely without fear of criticism. Once a list of alternatives has been generated, group members evaluate the solutions by discussing the positive and negative consequences of each alternative, select the best possible solution that meets the team's goals, and take action.

\section{Relational/Interaction Competencies}

\section{Competency 4: Group Dynamics}

Group dynamics includes effectively communicating a team member $=\mathrm{s}$ own ideas and encouraging the contribution of others' ideas. A team member should actively contribute his/her own ideas to the discussion without monopolizing the meeting time. Listening actively involves concentrating on what others are saying rather than formulating what you will say next and responding verbally by asking questions, paraphrasing, and building upon others' ideas. A team member can encourage others' participation by being nonverbally responsive (maintaining eye contact, nodding the head, leaning forward, smiling, etc.) and being verbally responsive to others' ideas and 
actively soliciting the participation of quieter team members. Overall, an atmosphere of collaboration should be established through consultation with others, asking relevant questions, and addressing other members' concerns and ideas.

\title{
Competency 5: Conflict Resolution
}

Conflict is a healthy part of team communication because it challenges members to seek information and to think more critically about the issues. Conflict can occur simply because of misunderstandings or when people simply disagree. An effective team member will deal with conflict in a way that is constructive rather than destructive to the team. When conflict does occur, the effective team member focuses on issues, information, and evidence rather than personalities. Oftentimes in teams, there are members who play dysfunctional roles such as disrupting or monopolizing the discussion and those that simply do not participate or carry their fair share of the workload (free riders). These problems should be addressed by describing the behavior rather than attacking the individual. A conflict due to a difference of opinion on an issue should include generating multiple solutions to the conflict and basing the decision on objective criteria on which the team can agree. Overall, conflict resolution should include objectivity that will create a supportive rather than a defensive climate.

\section{Appendix}

\author{
Team/Leadership Skills Rubric \\ Division of Business and Accountancy
}

Name of fellow team member being assessed:

Directions: For each competency, check the skills you observed your fellow teammate exhibiting. Then, circle a number on a scale of 1-5 (5 being a superior performance of the competency) above the statement that best describes your fellow teammate's behavior.

\begin{tabular}{||l|l|l||}
\hline \hline Competency 1: Organization and Coordination \\
\hline 1. Organization & $\begin{array}{l}\text { Assists in assignment of roles } \\
\text { and responsibilities }\end{array}$ & $\begin{array}{l}\text { Contributes to the definition } \\
\text { of team goals }\end{array}$ \\
\hline \multicolumn{1}{|c|}{2} & \multicolumn{1}{|c||}{3} & 4 \\
\hline $\begin{array}{l}\text { Does not contribute to (1.) } \\
\text { assigning roles or (2.) defining } \\
\text { goals. }\end{array}$ & $\begin{array}{l}\text { Assists in (1.) assigning roles and } \\
\text { (2.) defining goals. }\end{array}$ & $\begin{array}{l}\text { Assumes leadership role in (1.) } \\
\text { assigning roles and (2.) defining } \\
\text { goals. }\end{array}$ \\
\hline \hline
\end{tabular}

\begin{tabular}{||l|l|l||}
\hline 2. Coordination & $\begin{array}{l}\text { Assists in prioritizing and } \\
\text { coordinating tasks }\end{array}$ & $\begin{array}{l}\text { Helps integrate individual } \\
\text { contributions into team's } \\
\text { final product }\end{array}$ \\
\hline \multicolumn{1}{|c|}{2} & \multicolumn{1}{|c||}{3} & 4 \\
\hline $\begin{array}{l}\text { Does not contribute to either (1.) } \\
\text { prioritizing and coordinating tasks } \\
\text { or (2.) integrating individual } \\
\text { contributions into the final product. }\end{array}$ & $\begin{array}{l}\text { Assists in (1.) prioritizing and } \\
\text { coordinating tasks to meet deadlines } \\
\text { and/or (2.) integrating individual } \\
\text { contributions into the final product. }\end{array}$ & $\begin{array}{l}\text { Assumes leadership role in (1.) } \\
\text { prioritizing and coordinating tasks } \\
\text { and/or (2.) integrating individual } \\
\text { contributions into final product. }\end{array}$ \\
\hline
\end{tabular}




\begin{tabular}{||l|l|l||}
\hline \multicolumn{2}{||l|}{ Competency 2: Participation } \\
\hline $\begin{array}{l}\text { Attends meetings } \\
\text { consistently and punctually }\end{array}$ & $\begin{array}{l}\text { Consistently completes team } \\
\text { assignments and tasks on time }\end{array}$ & $\begin{array}{l}\text { Carries own share of } \\
\text { team's responsibilities }\end{array}$ \\
\hline \multicolumn{1}{|c|}{2} & \multicolumn{1}{c||}{3} & 4 \\
\hline $\begin{array}{l}\text { (1.) Frequently misses meetings or } \\
\text { arrives late, (2.) misses deadlines, } \\
\text { share of responsibilities. }\end{array}$ & $\begin{array}{l}\text { (1.) Infrequently misses meetings or } \\
\text { arrives late, and (2.) satisfactorily } \\
\text { completes assignments in a timely } \\
\text { manner. }\end{array}$ & $\begin{array}{l}\text { (1.) Punctually attends and is well } \\
\text { prepared for all meetings; (2.) all } \\
\text { assignments are of high quality and } \\
\text { meet deadlines. }\end{array}$ \\
\hline
\end{tabular}

\begin{tabular}{||l|l|l||}
\hline \hline \multicolumn{1}{||l||}{$\begin{array}{l}\text { Competency 3: Problem Solving } \\
\text { and/or research }\end{array}$} & $\begin{array}{l}\text { Participates in team } \\
\text { brainstorming of solutions/ } \\
\text { alternatives to problem }\end{array}$ & $\begin{array}{l}\text { Assists in constructively } \\
\text { evaluating pros and cons of } \\
\text { generated solutions. }\end{array}$ \\
\hline 1 & \multicolumn{1}{|c||}{3} & 4 \\
\hline $\begin{array}{l}\text { Does not (1.) contribute } \\
\text { information/research, (2.) } \\
\text { brainstorm solutions, or (3.) assist } \\
\text { in evaluating solutions/ } \\
\text { alternatives. }\end{array}$ & $\begin{array}{l}\text { (1.) Contributes } \\
\text { information/research, (2.) } \\
\text { brainstorms solutions, and (3.) } \\
\text { assists in evaluating solutions/ } \\
\text { alternatives. }\end{array}$ & $\begin{array}{l}\text { (1.) Contributes } \\
\text { information/research, (2.) offers } \\
\text { insightful or creative solutions, and } \\
\text { (3.) provides a framework for } \\
\text { evaluating solutions/ alternatives. }\end{array}$ \\
\hline
\end{tabular}

\begin{tabular}{|c|c|c|c|}
\hline \multicolumn{4}{|l|}{ Competency 4: Group Dynamics } \\
\hline \multicolumn{2}{|l|}{ Participates in team discussion } & \multicolumn{2}{|c|}{ Does not monopolize team's discussion time } \\
\hline \multicolumn{2}{|c|}{$\begin{array}{l}\text { Listens actively by paraphrasing/building upon } \\
\text { ideas of others }\end{array}$} & \multicolumn{2}{|c|}{ Encourages others to participate } \\
\hline 2 & & & 5 \\
\hline $\begin{array}{l}\text { (1.) Monopolizes team's discussion } \\
\text { time, (2.) does not listen to others, } \\
\text { (3.) does not encourage } \\
\text { participation of others, OR (4.) } \\
\text { does not contribute to discussion. }\end{array}$ & $\begin{array}{l}\text { (1.) Participa } \\
\text { monopolizin } \\
\text { listens to oth }\end{array}$ & $\begin{array}{l}\text { out } \\
\text { sion, and (2.) }\end{array}$ & $\begin{array}{l}\text { (1.) Participates without } \\
\text { monopolizing discussion, (2.) } \\
\text { builds upon ideas of others, and } \\
\text { (3.) actively encourages the } \\
\text { participation of others. }\end{array}$ \\
\hline
\end{tabular}

\begin{tabular}{|c|c|c|c|}
\hline \multicolumn{4}{|l|}{ Competency 5: Conflict Resolution } \\
\hline \multicolumn{2}{|c|}{ Emphasizes issues rather than personalities } & \multicolumn{2}{|c|}{ __ Offers constructive solutions to conflict } \\
\hline \multicolumn{2}{|c|}{$\begin{array}{l}\text { Constructively addresses free-riders (members } \\
\text { not contributing adequately to team) }\end{array}$} & \multicolumn{2}{|c|}{ _ Resolves conflict using objective criteria } \\
\hline 2 & & & 5 \\
\hline $\begin{array}{l}\text { (1.) Offers no constructive } \\
\text { solutions to resolve conflict, or (2.) } \\
\text { undermines conflict resolution by } \\
\text { emphasizing personalities rather } \\
\text { than issues. }\end{array}$ & $\begin{array}{l}\text { (1.) Offers } \mathrm{s} \\
\text { conflict, and } \\
\text { rather than } \mathrm{p}\end{array}$ & $\begin{array}{l}\text { to resolve } \\
\text { hasizes issues } \\
\text { ies. }\end{array}$ & $\begin{array}{l}\text { (1.) Resolves conflict based upon } \\
\text { objective criteria, (2.) encourages } \\
\text { win-win solutions, and (3.) } \\
\text { addresses free-rider problem } \\
\text { constructively without creating } \\
\text { hostilities. }\end{array}$ \\
\hline
\end{tabular}




\section{Evaluation of Entire Team}

Definition of a Team: A team is a small set of individuals with complementary skills who create a synergic effect while holding one another accountable for a common purpose. Teams on a continuous basis exhibit problemsolving behaviors and share leadership activities.

Directions: Rate your team on the three dimensions below. Circle a number on a scale of 1-5 (5 being a superior performance of the dimension) above the statement that best describes the behavior of your team as a whole

\begin{tabular}{|l|l|l||}
\hline \multicolumn{1}{|l|}{ Dimension One: Mutual Accountability and Leadership } \\
\hline 1 & \multicolumn{1}{|c|}{3} & 4 \\
\hline $\begin{array}{l}\text { Single dominate leader who holds } \\
\text { members accountable, plans, } \\
\text { directs, and coordinates members' } \\
\text { work. }\end{array}$ & $\begin{array}{l}\text { Some but not all members hold each } \\
\text { other accountable and share } \\
\text { leadership tasks. }\end{array}$ & $\begin{array}{l}\text { All members are accountable to } \\
\text { each other and share leadership } \\
\text { tasks (i.e., planning, directing, and } \\
\text { coordinating). }\end{array}$ \\
\hline
\end{tabular}

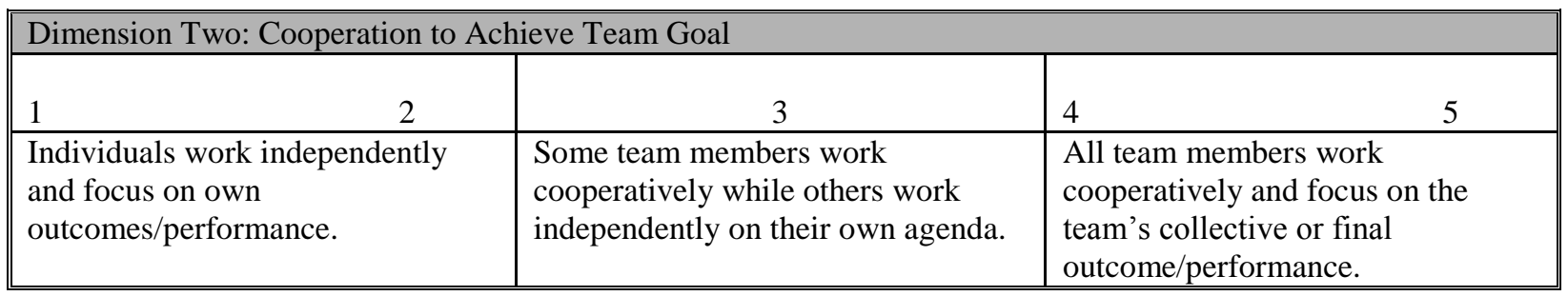

\begin{tabular}{|l|l|l||}
\hline \multicolumn{1}{|l|}{ Dimension Three: Cohesiveness Among Team Members } \\
\hline 1 & \multicolumn{1}{|c|}{3} & 4 \\
\hline $\begin{array}{l}\text { Social relationships are } \\
\text { characterized by a lack of } \\
\text { togetherness and a distrust of } \\
\text { members. }\end{array}$ & $\begin{array}{l}\text { Some but not all social relationships } \\
\text { are characterized by a sense of } \\
\text { cohesiveness and trust in one } \\
\text { another. Cliques exist. }\end{array}$ & $\begin{array}{l}\text { All social relationships are } \\
\text { characterized by a sense of } \\
\text { cohesiveness, "we-ness", and trust } \\
\text { in one another. No cliques exist. }\end{array}$ \\
\hline
\end{tabular}

